\title{
ホスホリラーゼ—構造と機能
}

\section{福井俊郎, 中野憲一*}

\begin{abstract}
酵素タンパク質のアミノ酸配列が次々と解明され，そして 20年程前からはX線結晶解析による三次元構造の 研究が始まったが, 当然のごとくそれらは比較的分子量の小さい酳素タンパク質においてであった. それが 最近ではサブユニット分子量10万の領域にまで至ったのである. そしてジャガイモ, ウサギ筋肉, 大腸菌と いうまったく異なった材料起源の酵素について詳細な構造比較が行なわれ, 分子進化の問題も提起されてい る.
\end{abstract}

酵素タンパク質における構造と機能の関連性 は, 生化学にとって基本的で重要な問題である. この問題が多くの生化学者によって取り上げられ るようになって久しい. その間に，タンパク質の 一次および高次構造解析法の著しい進歩を基盤に して，この問題に対する理解は驚くほどに発展し た.へモグロビン, リゾチーム、リボヌクレアー ゼ，種々のプロテアーゼなどの機能は，目で見る ように細部まで理解されるよらになってきた。し かしながら，これらのよく研究された酵素タンパ ク質を眺めると，いずれも分子量の比較的小さい ものであり，その機能も比較的単純なものであ る. 生物界には, より複雑な機能をもつ大きな分 子量のタンパク質が多いが，それら巨大なタンパ ク質の構造解析には計り知れぬ多くの困難がつき まとうため，研究は大幅に遅れていた。

サブニニット分子量 10 万というホスホリラー ゼの構造研究にも多くの問題があったが，ここ数 年の間にそれらの大部分が克服され，この酵素タ ンパク質の機能に対する構造的根拠の理解がまた 一段と深められることになった．ここでは，ホス ホリラーゼの化学的研究のあらましを, 筆者らの 最も新しい研究を中心にして解説する。なお，よ り専門的な知見については，他の総説 ${ }^{(1-10)}$ およ゙゙ それらに引用されている原著論文を参照していた だきたい。

\footnotetext{
* Toshio FUKUI, Kenichi NAKANO, 大阪大学産業科 学研究所
}

\section{起源の異なるホスホリラーゼ}

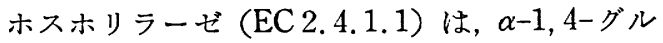
カン鎖を非還元性末端から順次加リン酸分解して $\alpha$-グルコース-1-リン酸（G1P）をつくる酵素で あるが，反応が可逆的であるために， G 1 P から 高分子量の $\alpha-1,4-$ グルカン鎖を合成することも できる. 動物缄器の中でホスホリラーゼの含量が 高い筋肉と肝臓の細胞内では, G 1 P の濃度に比 ベて無機オルトリン酸 $\left(\mathrm{P}_{\mathrm{i}}\right)$ の濃度が高いので, この酵素は生理的にはもっぱらグリコーゲン分解 の方向に働いている. 一方, 高等植物でも, 種子, 塊茎, 塊根などに多量に含まれているが，その生 理的役割については動物の場合ほど明らかではな い. 微生物にも，ホスホリラーゼの存在する例が 多く知られている. 大腸菌では，マルトースを炭 素源にして培養した時に誘導的に生成される.

筋肉のホスホリラーゼが複雑な調節性をもつこ とは古くから知られていたが，筋肉中に沶いて， この酵素は活性な $a$ 型と不活性な $b$ 型として存 在する. $b$ 型酵素は，ホスホリラーゼキナーゼに よって特定の Ser がリン酸化されると $a$ 型酵素 に転換し，ホスホリラーゼホスファターゼによっ て脱リン酸化されると, もとの $b$ 型酵素にもどる. 一方で, $b$ 型酵素は AMP が結合すると, $a$ 型酵 素と同程度の活性を示す．筋肉ホスホリラーゼに 見いだされたこのような二重の調節性は,タンパ ク質の機能調節に関する 2 つの基礎概念，すな わち，共有結合的な調節と非共有結合的（=アロ 
表 1 異なった起源のホスホリラーゼの調節性とグ ルカン特異性の比較

\begin{tabular}{|c|c|c|c|c|}
\hline \multirow{2}{*}{ 酵素起源 } & \multicolumn{2}{|c|}{ 調節性 } & \multicolumn{2}{|c|}{ グルカン特異性 } \\
\hline & 紧花 & AMP & 好 & 良 \\
\hline ウサギ筋肉 & + & + & $\begin{array}{l}\text { グリコーゲソ } \\
\text { アミロペクチン }\end{array}$ & $\begin{array}{l}\text { アミロース } \\
\text { マルトデキスト } \\
\text { リン }\end{array}$ \\
\hline ジャガイモ & - & $(-)$ & $\begin{array}{l}\text { アミロペクチン } \\
\text { アミロース } \\
\text { マルトデキスト } \\
\text { リン }\end{array}$ & グリコーゲン \\
\hline 大腸 菌 & - & $( \pm)$ & $\begin{array}{l}\text { マルトデキスト } \\
\text { リソ }\end{array}$ & $\begin{array}{l}\text { グリコーゲン } \\
\text { アミロペクチン }\end{array}$ \\
\hline
\end{tabular}

（）は結論が不明確であることを意味する。

ステリック）な調節を生み出すのに役立った.

しかしながら，このような二重の調節性は必ず しも, すべての起源のホスホリラーゼに当てはま るものではない(表 1). ジャガイモやトウモロコ シのよらな高等植物組織から精製されたホスホり ラーゼは, 常に活性型として存在し, AMP によ って活性化されないし，リン酸化-脱リン酸化を 受けることもない。 また，大腸菌のホスホリラー ゼも，リン酸化-脱リン酸化を受けることがない. 大腸菌のホスホリラーゼに AMP を加えると， 比活性が数倍上昇するといわれたことがあった が，最近では，むしろ AMP による活性化はない ものとみられている。

一方，基質グルカンに対する特異性も，ホスホ リラーゼの起源によって大きく異なっている（表 1). ウサギ筋肉 ホスホリラーゼは，グリコーゲ ンやアミロペクチンのような枝分かれをもつ $\alpha-$ グルカンを良い基質にするが，直鎖のアミロース やマルトデキストリンにはうまく㗢かない，それ に対して, ジャガイモのホスホリラーゼは, アミ ロペクチン（グリコーゲンよりも末端の直鎖部分 が長い), アミロース，マルトデキストリンなどを ほぼ同程度の良い基質とするが，グリコーゲンに 対する親和性は非常に低い。大腸菌のホスホリラ 一ゼはもっぱら，直鎖で枝の短いマルトデキスト リンを良い基質にする。

しかしながら，ホスホリラーゼは，起源がちが っても，その分子的な性質はよく似ている。いず れのホスホリラーゼも, 分子量約 10 万のサブユ ニットから成るダイマーまたはテトラマーとして
存在し, サブュニット当り 1 個のピリドキサール リン酸 (PLP) を結合している.この PLP はホ スホリラーゼの活性にとって必須であり, 酵素タ ンパク質からこれを除くと，酵素の活性は失くな ってしまう（最近，タピオカとバナナの葉のホス ホリラーゼは PLP を含まないという報告が出さ れているが，筆者らの最近の実験結果からする と，それらの報告は䛊りである可能性が高い). PLP は，アミノ酸代謝に 関連する多くの酵素の 補酵素として，その機能が明らかにされている が，ホスホリラーゼに拈けるその機能はまったく 異なっており，直接的な役割については最近まで 未解決の謎とされていた.

\section{一 次 構 造}

ウサギ筋肉ホスホリラーゼの全一次構造は，長 い年月の 困難な研究の 結果, 1977 年に米国ワシ

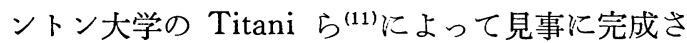
れた。 1 個のサブニニットは，アセチル基によっ てブロックされた Ser から始まる 841 残基のア ミノ酸から成るポリペプチド鎖で形成されてお り，分子量は 97,412 と計算された. 酵素的リン 酸化を受ける部位は，アミノ末端に近いSer-14

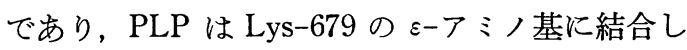
ている.この酵素はサブニニット当り 9 個の Cys を含むが，いずれも SH 型であり，分子内および 分子間に S-S 結合は存在しない。

一方, 筆者ら ${ }^{(12)}$ は 1984 年末むでに, ジャガイ モの ホスホリラーゼの 全一次構造決定を完了し た. 全アミノ酸残基数は 916 であり, 分子量は 103,916 と計算された。 これまでに，分子量 10 万を越すタンパク質で, タンパク質化学的手法に よって全アミノ酸配列順序が決定されたものは数 種に過ぎない，幸いにして，ジャガイモのホスホ リラーゼはその仲間入りをしたわけである，最 近, 西ドイッの Palm ら ${ }^{(13)}$ は, 大腸菌のホスホリ ラーゼの遺伝子構造を解析し，その結果からアミ ノ末端側 658 残基のアミノ酸配列順序を推定し た.この研究は未完成であって，カルボキシ末端 側の構造は発表されていない。

図 1 にこれら 3 種の起源のホスホリラーゼにつ 
$r$ SRPLSDQEKRKQISVRGLAGVENVTELKKDFDRHLHFTL VKNRNVATPROYYFAHALTVRDHLVGRWIRTQQHYYEKDPKRIYYLSLQFYMGRTLQNTMY P TLSEK IHHPITEQGGESDLSSFAPDAASI TSSIKYHAEFTPVF SPERFELPKAFFATAQSVRDSLL INWNATYDIYEKLNMKQAYYLSMEFLQGRALLNAIG

r NLALENACDEADYQLGLONEELEEI EEDAGLGNGGLGRLAACFLDSMATLGLAAYGYGIRYEFGLFNQK ICGGWQMEEADDWLRYGNPWEKARPEFTLPV p NLELTGAFAEALKNLGHNLENVASQEPDAALGNGGLGRLASCFLDSLATLNYPAWGYGLRYKYGLFKQRITKDGQEEVAEDWLE IGSPWEVVRNDVSYPI e NLGWYQOVQUSLKAYDINLTDLLEEE I DPAL GNGGLGRLAACFLOSMATVGQSATGYGLNYQYGLFRQSFVDGKQVEAPDDWHRSNYPWFRHNEALDVQV

$r$ HFYGRVEHTSQGAK-WVDTUVVLAMPYDTPVPGYRNNVVITMRLWSAKAPN-DFNLKDFNVGGYIQAVLDRNLAENISRVLYPNDNFFEGKELRLKQEYFVV P KFYGKVSTGSDGKRYWIGGEDIKAVAYDVPIPGYKTRTTISLRLWSTQVPSADFDLSAFNAGEHTKACEAQANAEKICYILYPGDESEEGKILRLKQQYTLC e GIGGKVTK--DGR--WEPEFTITGQAUTLPVVGYRNGVAQPLRLWQATHAH-PFDLTKFWDGDFLRAEQOQG INAEKL TKVLYPNDNHTAGKKLRLIQQYFOC

320 r AATLQDIRRFKSSKFGCROPVRTNFDAFPDKVAIQLNDTHPSLAIPELMRVLVDLERLDWDKAWEVTVKTCAYTNHTVLPEALERWPVHLLETLLPRHLQ

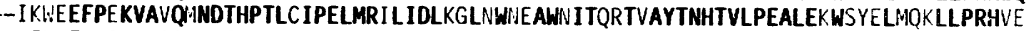
e ACSVADT IRRH--HLAGR-----EL.HELADYEVIQLNDTHPTIAIPELLRVLIDEHOHISWDDAWAITSKTFAYTNHTLYPPEALERWDVKLVKGLLPRHMQ
420 AAAFPGD

$r$ IIYEINORFLNR

P IIEA IDEEL VHE IVLKYGSMDLNKLEEKLTTMRILENFDLPSSVAELF I KPEISVDDOTETVEVHDKVEASOKVVTNDEDDTGKKTSVKIEAAAEKDI

$e$ IINEINTRFKTLV-

$r$ VDRLRRMSL VEEGAVKR INMAHLCIAGSHAVNGVARIHSEILKKTIFKDFYELEPHKFONKTNGITPRRWL VL CNFGLAE P DKKTPVSPEPAVIPPKKVRMANLCVVGGHAVNGVAE IHSE IVKEEVFNDFYELWPEKFQNKTNGVTPRRWIRF CNPPLSA e EKVIIAKLAVVHD---KQVHMANLCVVGGFAVNGVAALHSDL VVKDLFPEYHQLWPINKFHNVTNGITPRRWIKOCNPALAA

520

540

560 580

r IIAERIG-EEYISDLDQLRKLLSYVDDEAFIRDVAKVKOENKLKFAAYLEREYKVHINPNSLFDVQVKRIHEYKRQLLNCLHVITLYNRIKK-_--EPNKFVVRR $\rho$ IITKWTGTEDWVLKTEKLAELQKF ADINEDLONEWREAKRSNKIKVVSFLKEKTGYSVVPDAMFDIQVKRIHEYKRQLLNIFGIVYRYKKMKEMTAAERKTNF VPR e LLOKSLQ-KEWANDLDQL INLVKL ADDAKFRDLYRVIKHANKVRLAEFVKVRTGIDINPQAIFDIQIKRLLEYKRQHLNLLRILALYKE IRQ- -NPQADRVPR

620

640

$\begin{array}{ccccc}620 & 640 & 660 & 680 & 700 \\ & & 60 & 60\end{array}$

$\begin{array}{cccc}620 & 640 & 660 & 680\end{array}$

r TVMIGGKAAPGYHMAKMIIKL ITAIGDVVNHDPVVGDRLRVIFLENYRVSLAEKVIPAADLSEQISTAGTEASGTGNMKFMLNGALTIGTMDGANVEMAE P VCIFGGKAFATYVQAKR IVKF I TDVGATINHDPE I GDLLKVVFVPDYNVSVAELLIPASDLSEHISTAGNEASGTSNHKFANINGC IQIGTLDGANVEIRE e VFLFGAKAAPGYYLAKIUI IFA IUIKVADVINNDPL VGDKLKVVFLPDYCVSAAEKLIPAADI SEQISTAGKEASGTGNMKLALDGALTVGTLD

$\begin{array}{cccc}720 & 740 & 760 & 780\end{array}$

$\begin{array}{cccc}720 & 740 & 760 & 780\end{array}$

$\begin{array}{cccc}720 & 740 & 760 & 780\end{array}$

$\begin{array}{cccc}720 & 740 & 760 & 780\end{array}$

$\begin{array}{cccc}720 & 740 & 760 & 780\end{array}$ P EVGEENFFLFGAQAHE IAGLRKERADGKFVPDERFEEVKEFVR-SGAFGSYNYDDLIGSLEGNEGFGRADYFLVGKDFPSYIECQEKVDEAYRDQKRWTTMS

820 840

$r$ IRNIATSGKFSSORTIAQYARE IWGVEPSRQRLPAPDEKIP

p ILNTAGSYKFSSDRTIHEYAKDIWHIEAVEIA

\section{図 1 異なった起源のホスホリラーゼの一次構造比較}

$\mathrm{r}$ : ウサギ筋肉 ${ }^{(11)}, \mathrm{p}: シ ゙ ャ カ ゙ イ モ 乇^{(12)}, \mathrm{e}$ : 大腸菌 ${ }^{(13)}$. 番号はウサギ筋肉酵素の一次構造に基づく.フミノ酸は一字省 略符号で示した.太字は同じアミノ酸を示す.

$A=A l a, C=$ Cys, $D=A s p, E=G l u, F=P h e, G=G l y, H=H i s, I=I l e, K=L y s, L=L e u, M=M e t, N=A s n$, $\mathrm{P}=$ Pro, $\mathrm{Q}=\mathrm{Gln}, \mathrm{R}=\mathrm{Arg}, \mathrm{S}=$ Ser, $\mathrm{T}=\mathrm{Th} r, \mathrm{~V}=\mathrm{Val}, \mathrm{W}=\mathrm{Trp}, \mathrm{Y}=\mathrm{Tyr}$

いて, 一次構造を比較する. 比較は構造類似性に 従い,できる限り少ない数の欠失と挿入しか加え ないようにした，その結果をみると，ウサギ筋肉 酵素とジャガイモ酵素のポリペプチド鎖の間で は，アミノ末端とカルボキシ末端がほぼ揃ってお り, 大した長さの差異はみられなかった. しかし ながら，ジャガイモ酵素のポリペプチド鎖の中央 付近には多数の余分なアミノ酸の配列があり, 78
残基から成る大きな挿入を加えることになった。 ウサギ筋肉酵素とジャガイモ酵素との間には，サ ブニニット分子量において約 8,000 の差がある ことが知られていたが，この差は今回ポリペプチ ド鎖の中央部に見いだされた大きな挿入によって 説明されるよらになった。

ウサギ筋肉, ジャガイモ拈よび大腸菌のホスホ リラーゼに関するこのような比較に基づくと， 3 


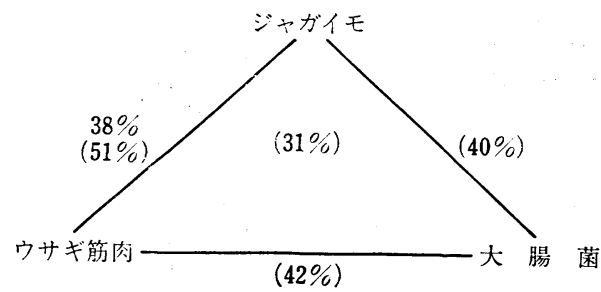

図 2 異なった起源のホスホリラーゼの構造類似性 数字はそれぞれの酵素間の同じアミノ酸の割合を示す. 中 央の数字は 3 種の酵素間での割合，（）内の数字は残基番 号 1〜692 の比較を示す. ジャガイモーウサギ筋肉間の類似 性は,アミノおよびカルボキシ末端部分と 78 残基の大きな 挿入部分を除くと，43\%になる。

種のホスホリラーゼの間では半数に近いアミノ酸 残基が二致する（図 2).さらに，性質の類似する アミノ酸の間での置換も加えると，構造類似性は これよりもずっと高くなる。このような構造類似 性が存在するだろうことは，すでに，ジャガイモ 酵素のアミノ酸組成 ${ }^{(14)}$ 执よび Cys 含有ペプチド の構造解析 ${ }^{(15)}$ の結果から予想していたが，今回明 確に実証できたわけである.

大きく起源と性質の異なった 3 種のホスホリラ 一ゼの間で, このように高い一次構造的な類似性 があるということは，これらのホスホリラーゼが 1 つの共通な祖先タンパク質から進化してきたこ とを示唆している. 現在みられる調節タンパク質 の中には，明らかに触媒サブニニットと調節サブ ユニットとの融合によってできたと思われるもの （例. cGMP 依存性タンパク質キナーゼ, $\mathrm{Ca}^{2+}$ 依 存性プロテアーゼなど）もあるが，ホスホリラー ゼの場合には，これらの例とは異なり，昔から 1 本の長い（分子量約 10 万の） ポリペプチド鎖か ら進化してきたものと想像される.

\section{高 次 構 造}

ウサギ筋肉ホスホリラーゼの X 線結晶解析によ る立体構造の解明も，ここ数年の間に急速に進め られた．英国のオクスフォード大学では $b$ 型酵 素・IMP 複合体の 結晶が, カナダのアルバータ 大学（最近では米国のカリフォルニア大学サンフ ランシスコ分校に受け継がれている）では $a$ 型 酵素・グルコース複合体の結晶が解析され，現在 までに $2 \AA$ 分解能程度まで精密化されつつあ
る ${ }^{(1,3,6)}$. その結果, ポリペプチド鎖の折れたたみ は無論のこと, 各アミノ酸残基の 側鎖の 位置ま で，ほぼ決定されることになった（ただし，現在 解析されているこれらの酵素・リガンド複合体 は，いずれも不活性な $\mathrm{T}$ 型酵素であって，活性な $\mathrm{R}$ 型酵素の解析はまだ行なわれていないことを指 摘しておかなければならない)。

一方，ジャガイモのホスホリラーゼの X線結晶 解析は，残念ながら，これまでの種々の試みにか かわらず，あまり進んでいない，したがって，直 接的にその立体構造について議論することはでき ない。しかしながら，幸いにも，ウサギ筋肉酵素 との間に高い一次構造類似性があることがわかっ たので，その類似性の程度から判断して，これら のホスホリラーゼのポリペプチド鎖はいずれも同 様な折れたたみをもつるのと考えることにした。 そこで，ジャガイモ酵素の一次構造をウサギ筋肉 酵素の立体構造の対応する部分に当てはめた (図 3).

ウサギ筋肉ホスホリラーゼの 1 つのサブュニッ トは，2つのほぼ同じ大きさのドメインからでき ていて，それぞれのドメインには，中心に $\beta$-シ 一トから成る芯の 部分があり，その 周囲を $\alpha$-へ リックスの層が取り巻いている，ウサギ筋肉酵素 とジャガイモ酵素との間の一次構造比較（図 1) に際して，合計 8つの拥入と欠失を加えたが，そ れらはすべてサブュニットの表面またはサブニニ ットとサブュニットとの接触面に存在しており， 基本骨格を作っている $\beta$-シートの中には見られな かった（図 3 ). また，中心部のアミノ酸残基は非 常によく保存されていて， $2 / 3$ 以上のアミノ酸が 同一である. 特に, 補酵素 PLP を含む分子中央 部にある活性部位は，ほとんど完全に保存されて いる.さらに, カルボキシ末端側 560〜710 番が 形成しているジヌクレオチド結合折れたたみ (“Rossmann fold”) の部分も高い類似性を示し, $58 \%$ のアミノ酸が同一である.それに反して，分 子周辺に存在する $\alpha$-ヘリックスやュイルの部分 の保存性は低く，性質の異なる側鎖のアミノ酸に 置換されている例も多くみられる.

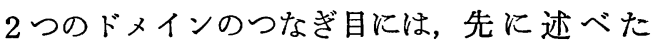




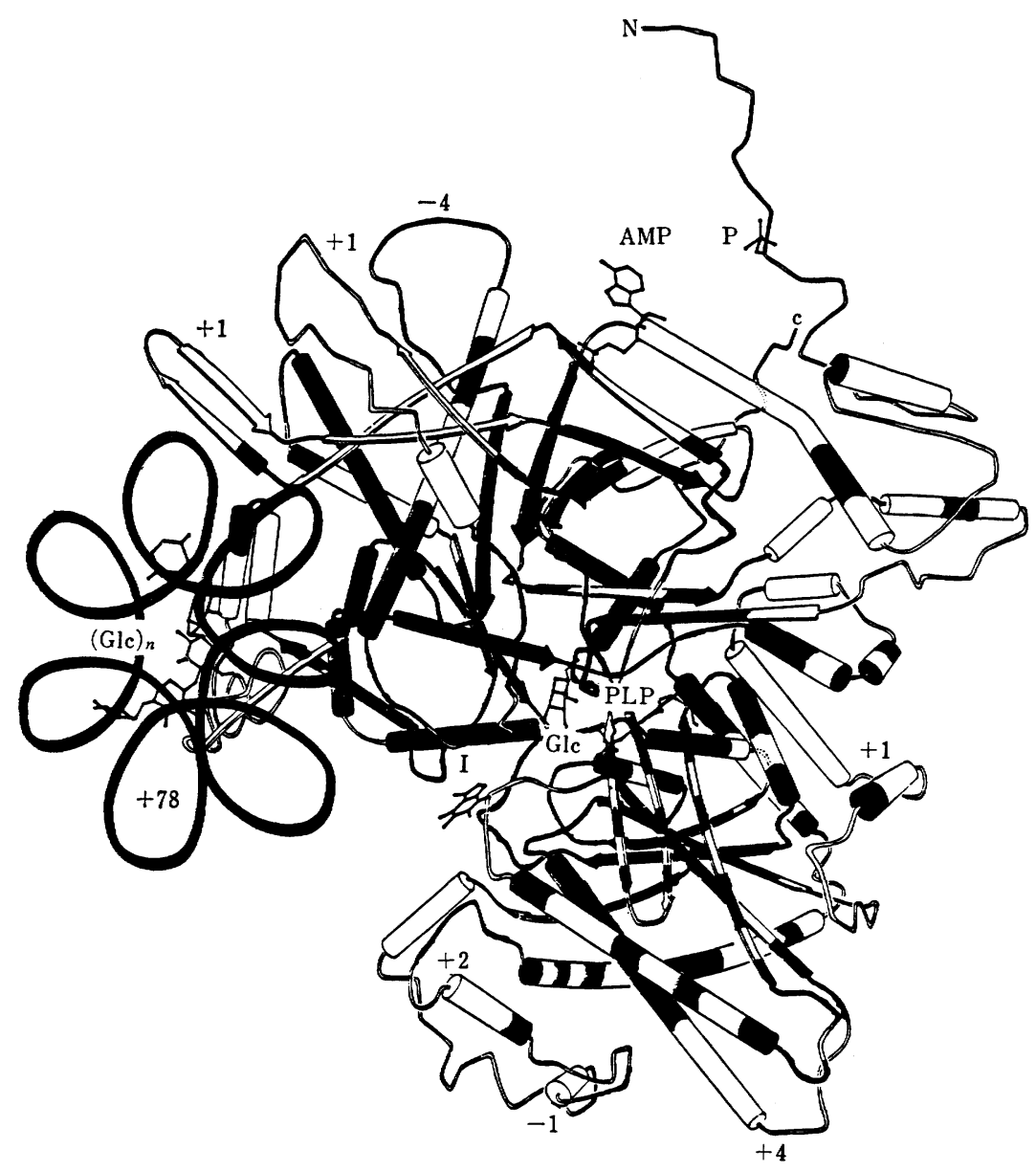

図 3 ウサギ筋肉ホスホリラーゼとジャガイモホスホリラーゼの立体構造上での比較 ウサギ筋肉酵素の立体構造概念図 ${ }^{(€)}$ にジャガイモ酵素の一次構造 ${ }^{(12)}$ を当てはめて，類似性の高い部分を黒く泾った. P： リン酸化部位, AMP : AMP 結合部位, PLP : ピリドキサールリン酸, Glc : グルコース結合部位（基質 G $1 \mathrm{P}$ 同じ場 所に結合する), I : 阻害剂結合部位, $(\mathrm{Glc})_{n}$ ：グルカン貯蔵部位， $\mathrm{N}$ ：アミノ末端， $\mathrm{c}$ ：カルボキシ末端. 数字は挿入ま たは欠失の場所と残基数を意味している.

78 残基から成る大きな挿入がみられる。この挿 入部分はきわめて特徵的な一次構造をもち，その 他の部分の構造とは大きく異なっている.すなわ ち,この挿入部分には Asp, Glu, Lys を主とす る解離性アミノ酸残基が多く，この部分全体の半 数近くを占めている. それに対して, 別の解離性 アミノ酸であるArg, および芳香族アミノ酸はき わめて少ない。 また, 同じアミノ酸が $2 \sim 3$ 個続 いてクラスターを作っているのも目につく. 二次 構造の予測をすると, この部分はすべて $\alpha$-ヘリ ックスを作っており，1つの独立した突出部分に なっていると考光られる。

先に筆者らの研究室では, ジャガイモのホスホ
リラーゼにプロテアーゼを作用させると，ポリペ プチド鎖の中央部付近で優先的に限定分解が起こ るが，この限定分解を受けても，酵素活性にはほ とんど変化がないことを報告していた(16). 今度の 研究で，この限定分解を受ける部分がちょらどこ の突出部分にあることがわかった． ウサギ筋肉ホ スホリラーゼでは，この部分にグリコーゲン貯蔵 部位が存在している.グリコーゲン貯蔵部位の機 能とジャガイモ酵素にみられる突出部分との関係 については, 別の章で述べることにする.

\section{調節部位/リン酸化とアロステリック調節}

ホスホリラーゼキナーゼによってリン酸化を受 
けるSer 周辺のアミノ酸配列順序は, 種々の動物 の骨格筋およびゥサギ肝臓のホスホリラーゼにお いて，非常によく似ている（図 4). ホスホリラー ゼキナーゼの基質特異性を決定するといわれてい る残基（Ser-14 の前にある Lys と Arg のクラス ターおよび後にある Arg）は, 種々の動物ホスホ リラーゼに拈いてよく保存されており，これらの ホスホリラーゼはいずれもウサギ筋肉から精製さ れたホスホリラーゼキナーゼによってよくリン酸 化を受ける。それに対して，酵素的リン酸化を受 けないジャガイモと大腸菌のホスホリラーゼで は, この付近の一次構造がまったく異なっている (図 4) (13,17).ただ, ジャガイモのホスホリラーゼ には，酵母ホスホリラーゼのリン酸化部位にある 程度の類似性をもつ部分が存在する。この部分に あるSer が，酵母のホスホリラーゼキナーゼによ ってリン酸化を受けるかもしれない。

ウサギ筋肉ホスホリラーゼに拈いて, AMP 結 合部位はリン酸化部位の 近くで, サブニニットー サブュニット間の接触領域（図 3 では上部に相当 する）に存在する. ウサギ筋肉, ジャガイモ, 大 腸菌のホスホリラーゼに抢いて, AMP 結合部位 を構成するアミノ酸はほとんど保存されていな い(17). Shimomura と Fukui(18) は, ウサギ筋肉ホ スホリラーゼが AMP と結合した時にみられる 円二色性変化を解析して, AMP のアデニン環と 芳香族アミノ酸残基の側鎖との間にスタッキング 相互作用が起こることを示唆した. その後の化学 修飾とX線結晶解析の結果から，このスタッキン
グ相互作用を起こすのは Tyr-75 と決定され $た^{(1,3)}$. その Tyr-75 は, ジャガイモと大腸菌のホ スホリラーゼでそれぞれ Glu と Pro に置換して いる．また，ウサギ筋肉酵素で AMP の $2^{\prime}-\mathrm{OH}$ と水素結合するといわれている Asn-44 と Gln71 は，他のホスホリラーゼではいずれも他のア ミノ酸に置換されている. AMP のリン酸基とイ オン結合する Arg-242 と Arg-308 のうち, Arg242 は保存されているが, Arg-308 のほうはジャ ガイモ酵素と大腸菌酵素でいずれも Ile に置換し ている.これらの結果からみて，ジャガイモと大 腸菌のホスホリラーゼには, AMP 結合部位は存 在しないものと思われる。この結論は，両ホスホ リラーゼが AMP によって活性化を受けないと いら事実と一致する.

ウサギ筋肉ホスホリラーゼがリン酸化または AMP の結合によって活性化される時に，どのよ うな構造変化が起こるかは，興味深い問題である が, 先にも述べたように, 現在X線結晶解析の行 なわれているホスホリラーゼはいずれも不活性型 であるために，まだ十分な結論が得られていな い. 今後, 活性型としてのみ存在するジャガイモ または大腸菌のホスホリラーゼの立体構造との比 較が進むと,この問題も解決されてくることだろ 亏.

\section{グリコーゲン貯蔵部位/グルカン基質特異性}

ウサギ筋肉ホスホリラーゼの $\mathrm{X}$ 線結晶解析の結 果から，基質グルカンは，PLP 部位から 25〜30

$\begin{array}{llllllllllllllllllllllll}1 & 2 & 3 & 4 & 5 & 6 & 7 & 8 & 9 & 10 & 11 & 12 & 13 & 14 & 15 & 16 & 17 & 18 & 19 & 20 & 21 & 22 & 23 & 24\end{array}$ rm Ac-Ser-Arg-Pro-Leu-Ser-Asp-Gln-Glu-Lys-Arg-Lys-Gln-Ile-Ser-Val-Arg-Gly-Leu-Ala-Gly-Val-Glu-Asn-Val(P)

h

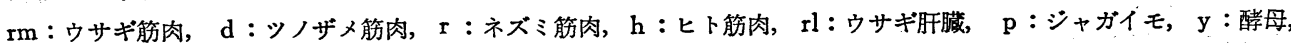
$\mathrm{e}$ : 大腸菌. 番号はウサギ筋肉酵素の一次構造に基づく.（P）はリン酸化部位を示す. (P)

Pro-

Ser-Gln-Pro-Ile-Phe-Asn-Asp- 
Å離れた別の部位に結合するといら奇妙な結果

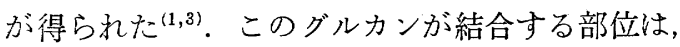
“グリコーゲン貯蔵部位”と名づけられた。グリ コーゲンのような分枝の多いグルカンは一旦この 部位で固定され，その後で，末端鎖の 1 つが PLP 部位へ入り，そこで触媒反応を受けるものと説明 された。このように，活性部位とは別の部位にグ リコーダンが結合するということは，先にグリコ ーダン合成酵素についていわれたことがあった が， ウサギ筋肉ホスホリラーゼについて初めて実 証されたわけである。ともあれ，この考光によっ て, ウサギ筋肉ホスホリラーゼが, 分枝の多いグ リコーゲンを良い基質汇するが，直鎖のグルカン にはうまく働かないという事実をらまく説明でき たわけである。

それでは，直鎖のグルカンる良い基質にするこ とのできるジャガイモのホスホリラーゼの場合に は，どらなっているのだろらか. Shimomura と Fukui(19) は先に, PLP 部位をブロックしたホス ホリラーゼとブロックしないホスホリラーゼにっ いて，種々のグルカンの親和性を比較した．その 結果から, ジャガイモ酵素には, ウサギ筋肉酵素 にみられるようなグルカン貯蔵部位は存在せず， 基質グルカンは直接的に PLP 部位に結合するこ とが示された.この結論は, ジャガイモのホスホ リラーゼがアミロース, アミロペクチン, マルト デキストリンをすべて良い基質にするといらジャ ガイモ酵素のグルカン基質特異性とよく一致し た.

ジャガイモのホスホリラーゼに抛いて，グリコ 一ゲン貯蔵部位に相当する部分には, 先に述べた ように大きな突出部分が余分に結合している.こ の突出部分の大きさは，コンパクトな球状タンパ ク質と仮定すると，直径 $20 \sim 25 \AA ̊ 丿$ となり、シト クロム $c$ に匹敵するほどの大きさになる。これで は，と.らてい，この部分にグルカンを結合させる ことはできない。

ジャガイモのホスホリラーゼには, PLP 部位 から少し離れた分子表面にシクロデキストリンを 結合する部位がある(199. この部位にシクロデキス トリンが結合すると, PLP 部位への グルカンの
結合が邪魔されて, 酵素活性が阻害される。 ウサ ギ筋肉ホスホリラーゼには，このようなシクロデ キストリンの阻害作用がみられない，その代わり に，この付近にアロステリックな阻害剤結合部位 が存在する ${ }^{(1,3)}$ 。この部位にはカフェインやアデ ノシンのようなヌクレオンド型化合物が 結合し て，阻害作用をひき起こす。ジャガイモホスホリ ラーゼとウサギ筋肉 ホスホリラーゼの構造比較 （因 3)をみると，PLP 部位に続くクレバスの入 口付近飞, 類似性の非常飞低い部位が存在する. このような構造上の相違が, 両ホスホリラーゼの 阻害剂仗対寸る性質の差異につながるのかもしれ ない。

\section{活性部位/触媒反応機構}

すでに指摘したように, ウサギ筋肉, ジャガイ モ, 大腸菌のホスホリラーゼ扎いて, 助醇素 PLP .の結合する部位打よびその 周辺の 構造は非 常によく保存されている. 類似性をるら少し微細 に検討してみよう. PLP の 4-アルデヒド基がシ ッ 塩基結合する Lys-679 の 周辺の一次構造は ほぼー致している(20). また, bis(5'-pyridoxal) diphosphate に上る親和標識から見つけられた Lys-573，拉よびその周辺の一次構造もよく保存 されている ${ }^{(21,22)}$. さらに, PLPの $5^{\prime}$-リン酸基に 続く部位で，基質 G1P の結合に関与する Leu139, Asn-282, His-376, Val-454, Asn-483 など もよく保存されている，その他，触媒作用関係 するといわれている Asp-338, Glu-671, His570, Asp-283 などもすべて保存されている。 こ のように，3種のホスホリラーゼに执いて，活性 部位の構造が注ぼ完全に保存されているといらこ そは，これらの酵素がすべて反応速度論的に共通 な反応機構, すなわら, “rapid equilibrium random $\mathrm{BiBi}$ に従うといら事実とよく一致する。

それでは，ホスホリラーゼの触媒反応に招い て，PLPはぞのような役割をするのだろらか.こ の問題について, 最近になり, 筆者らの研究室で は，PLP の $5^{\prime}$-リン酸基と基質 G1P のリン酸基 とをピロリン酸結合させた化合物，すなわち pyridoxal (5') diphospho- $\alpha$-D-glucose (PLDP-Glc) 


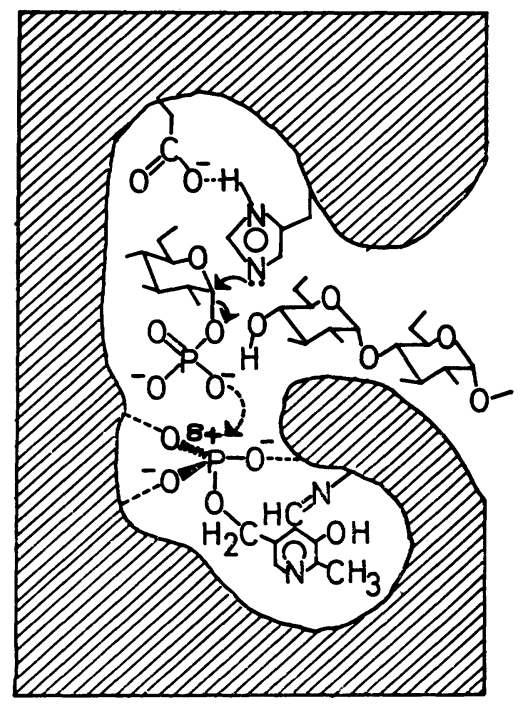

図 5 ホスホリラーゼ反灾機構におけるピリドキサ ールリン酸の役割(24)

詳細な機構の説明は本文参照.

をアポホスホリラーゼに結合させて，それにグル カンを加えると，ホスホリラーゼの本来の触媒反 応とまったく同じグルコシル基転移が起こること を見いだした(23). PLDP-Glc を用いた反応は, もとの反応に比べて速度は小さいが，反応様式の みならず，反応速度論およびェネルギー論的にみ ても，きわめてよく類似している(24)。これらの結 果から，ホスホリラーゼの触媒反応において， PLP の $5^{\prime}$-リン酸基と基質のリン酸基との間の直 接的な相互作用が重要であることは明らかであ る.

筆者らは，この反応系についてカナダの Madsen のグループと ${ }^{31} \mathrm{P}-\mathrm{NMR}$ に觡する共同研究を 行ない, その結果から，ホスホリラーゼの活性状 態では，PLP の $5^{\prime}$-リン酸基が周辺の正電荷と強 く相互作用することにより歪みを受け，リン原子 が分極により正に帯電して G1P のリン酸基か ら電子を引き寄せて，グリコシド結合を不安定化 するといら機構を提出した（図 5)(23 25). これに 対して, 西ドイッの Helmreich のグループでは, ホスホリラーゼの反応もグリコシダーゼの反応と 同じように，一般酸塩基触媒機構に従うものと考 え, PLP の $5^{\prime}$-リン酸基を一般酸にみている(26). この場合には, PLP の 5'-リン酸基から G1P の
リン酸基へプロトンが 1 つ移動するといらことに なる. 現在のところ，いずれの機構が正しいかに ついて決定的な証拠は得られていないが，いずれ にせよ，ホスホリラーゼの反応で，PLP の 5'-リ ン酸基が直接的に基質リン酸基と相互作用して触 媒作用していることは，筆者らの研究から明白で ある。このような PLP の触媒作用は，従来よく 研究されてきたアミノ酸代謝関連のビタミン $\mathrm{B}_{6}$ 依存性酵素の機構とはまったく異なっており，新 しい型の酵素反応である(9).

以上のようにして，筆者らが十数年前にホスホ

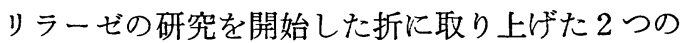
課題，すなわち，（1）活性調節をもつ動物ホスホ リラーゼは, 活性調節をもたない植物ホスホリラ 一ゼと, 構造的にどのように違っているのか, （2）ホスホリラーゼの反応に执いて，PLP はど のような直接的な役割をしているのか，について は，かなりの成果を得ることができた．さらに，当 初には考えていなかった問題，すなわち（3）木 スホリラーゼの間にみられるグルカン特異性の差 異にはどのような構造的根拠があるのか，という 問題に対しても確実な証拠を得ることができた.

残る問題として，ホスホリラーゼの触媒反応機 構の細部を明らかにする必要がある．この点につ いて筆者らの研究室でも研究が進行中であるが, 決定的な証拠を得るまでにはなお多くの困難が予 想される。 また，ジャガイモのホスホリラーゼの $\mathrm{X}$ 線結晶解析については, 西ドイッの Bühner が 研究中であり, 早い時期での成果を期待したい. また，初めにも述べたよらに，高等植物に拈ける ホスホリラーゼの生理学的意義については不明な 点が多い. この問題については, 緑葉のホスホリ ラーゼに関する研究から，解明の糸口がつかめる かもしれない，緑葉中には，少なくとも 2 種のホ スホリラーゼアイソザイムが存在しており，特に グルカンに高い親和性をもつ分子種は, 通常デン プンが存在していない細胞質（または液胞）中に 分布している(27). 機能的にも多くの特徽をもつこ の酵素の構造研究も今後望まれる課題である. 
筆者らの研究窒に淤るホスホリラーゼの研究には, 下村正 二博士をはじめ多くの共同研究者の努力が加わった. また, 研 究費の一部は文部省科学研究費補助金から得た：記して感謝の 意を表したい.

\section{文献}

1) R. J. Fletterick \& N. B. Madsen : Ann. Rev. Biochem., 49, 31 (1980).

2）福井俊郎：蛋白質 核酸 酵素，26，46 (1981).

3) J. A. Jenkins, L. N. Johnson, D. I. Stuart, E. A. Stura, K.S. Wilson \& G.Zanotti : Philos. Trans. Roy. Soc. London, B 293, 23 (1981).

4）福井俊郎, 中野憲一：蛋白質 核酸 酵素, 27, 1779 (1982).

5) T. Fukui, S. Shimomura \& K. Nakano: Mol. Cell. Biochem., 42, 129 (1982).

6) R. J. Fletterick \& S. R. Sprang: Acc. Chem. Res., 15, 361 (1982).

7) T. Fukui, M. Tagaya, M. Takagi \& S. Shimomura : "Chemical and Biological Aspects of Vitamin $\mathrm{B}_{6}$ Catalysis", Part A, Alan R. Liss, Inc., 1984, p. 161.

8) K. Nakano, Y. Kikumoto \& T. Fukui : "Chemical and Biological Aspects of Vitamin $\mathrm{B}_{6}$ Catalysis”, Part A, Alan R. Liss, Inc., 1984, p. 171.

9）福井俊郎：“酵素——ハイオテクノロジーへの指針”, II, 朝倉書店, 1985, p. 65.

10) S. Shimomura \& T. Fukui : Mem. Inst. Sci. Ind. Res., Osaka Univ., 42, 13 (1985).

11) K. Titani, A. Koide, J. Hermann, L. H. Ericsson, S. Kumar, R. D. Wade, K. A. Walsh, H. Neurath \& E. H. Fischer: Proc. Natl. Acad. Sci. USA, 74, 4762 (1977).

12) K. Nakano \& T. Fukui : submitted for publication in J. Biol. Chem.
13) D. Palm, R. Goerl, K. J. Burger, M. Bühner, M. Schwartz: "Chemical and Biological Aspects of Vitamin $\mathrm{B}_{6}$ Catalysis”, Part A, Alan R. Liss, Inc., 1984, p. 209.

14) A. Kamogawa, T. Fukui \& Z. Nikuni : J. Biochem., 63, 361 (1968).

15) K. Nakano, T. Fukui \& H. Matsubara: J. Biochem., 87, 919 (1980).

16) S. Iwata \& T. Fukui : Arch. Biochem. Biophys., 169, 58 (1975).

17) K. Nakano, T. Fukui \& H. Matsubara: J. Biol. Chem., 255, 9255 (1980).

18) S. Shimomura \& T. Fukui : Biochemistry, 15, 4438 (1976).

19) S. Shimomura \& T. Fukui : Biochemistry, 19, 2287 (1980).

20) K. Nakano, S. Wakabayashi, T. Hase, H. Matsubara \& T. Fukui : J. Biochem., 83, 1085 (1978).

21) S. Shimomura, K. Nakano \& T. Fukui : Biochem. Biophys. Res. Commun., 82, 462 (1978).

22) M. Tagaya, K. Nakano, S. Shimomura \& T. Fukui : J. Biochem., 91, 599 (1982).

23) M. Takagi, T. Fukui \& S. Shimomura : Proc. Natl. Acad. Sci. USA, 79, 3716 (1982).

24) M. Tagaya \& T. Fukui : J. Biol. Chem., 259, 4860 (1984).

25) S. G. Withers, N. B. Madsen, B. D. Sykes, M. Takagi, S. Shimomura \& T. Fukui : J. Biol. Chem., 256, 10759 (1981).

26) H. W. Klein, M. J. Im, D. Palm \& E. J. M. Helmreich : Biochemistry, 23, 5853 (1984).

27) T. Fukui : "The New Frontiers in Plant Biochemistry", ed. by T. Akazawa, T. Asahi and H. Imaseki, Japan Scientific Societies Press, 1982, p. 71.
荒井 綜一 (Soichi Arai) 昭和10年 10 月 29 日生 $<$ 略歴 $>$ 昭和 34 年東京大学農 学部農芸化学科卒業 $/$ 同年森永製菓(株) 入社 $/ 42$ 年東京大学農学部助手 $/ 53$ 年同 助教授, 現在にいたるく研究テーマと抱 負 >食品タンパク質の酵素による改質. 医療用食事素材としてのペプチドの開 発. コメ中の活性タンパク質, 特にシス テイン・プロテイナーゼ・インヒビター く趣味〉スポーツ一般, 宝堛歌劇

安斎 寞 (Hirosi Anzai) 昭和31 年 3 月 6 日生 $<$ 略歴 $>$ 昭和 53 年日本大学 農獣医学部水産学科卒業 $/ 55$ 年同大学大 学院農学研究科侪士課程修了/同年東北 大学大学院研究生 $/ 59$ 年同大学大学院博 士課程中退/同年日本大学農獣医学部水 産学科助手, 現在にいたるく研究テーマ と抱負〉海産無脊椎動物のセルロース分 解機構<趣味 $>\mathrm{SF}$ 小説, アニメーショ
池上 司郎 (Shiro Ikegami) 昭和 21 年 5 月 8 日生 <略歴>昭和 45 年東京大 学文学部心理学科卒業 $/ 50$ 年同大学大学 院人文科学研究科博士課程修了/同年三 菱化成生命科学研究所研究員 $/ 55$ 年医学 博士 (東京大学医学部) $/ 58$ 年同研究所 主任研究員, 現在にいたるく研究テーマ と抱負>記億・学習の神経機構とそれに 関与する神経伝達物質く趣味〉クラシッ ク音楽, カメラ, 旅行

石川 榮治 (Eiji Ishikawa) Vol.14, No.11, p.702 参照

石川 統 (Hajime Ishikawa) 昭 和 15 年 12 月 8 日生 $<$ 略歴>昭和 38 年東京 大学理学部生物学科卒業 / 43 年同大学大 学院修了(理博)／同年米国オレゴン州立
大学リサーチ・アソシェート/46年東京 大学教養学部基礎科学科助手 $/ 52$ 年同生 物学教室助教授, 現在にいたるく研究テ 一マと抱負 >細胸内共生の分子生物学. 何はともあれ，他人とは違うことをやる のを身上と心得ていますく趣味〉和製ミ ステリーの乱読, ビールの鯨飲

岩 井 譲 (Yuzuru Iwai) 昭和15年 9 月 26 日生 $<$ 略歴 $>$ 昭和 39 年東北大学農 学部農芸化学科卒業 /同年第一裂薬(株) 研究員 $/ 50$ 年北里研究所技師 $/ 55$ 年東京 理科大学薬学部非常䔙講師 $/ 58$ 年北里研 究所副部長 $/ 60$ 年同部長，現在にいた る. 農博 (東北大学) <研究テーマと抱 負 >微生物の生産する生物活性物質の探 索, 放線菌の分類. 微生物の限りない能 力を信じたいく趣味>スポーツ全般, 現 在は専らテニス 